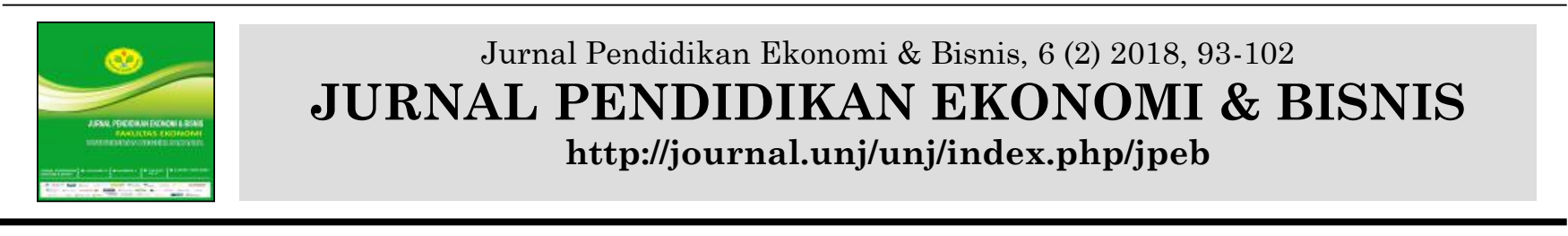

\title{
House Ownership Circumstances in Rural Area: Evidence from Indonesia
}

\author{
Thomas Soseco ${ }^{1^{*}}$, Dwi Wulandari ${ }^{* *}$, Sugeng Hadi Utomo ${ }^{3^{*}}$ \& Bagus Shandy Narmaditya ${ }^{4^{*}}$ \\ 1 Economic Department, The Waikato University, New Zealand \\ ${ }^{2}$ Faculty of Economics, Universitas Negeri Malang, Indonesia \\ ${ }^{3}$ Faculty of Economics, Universitas Negeri Malang, Indonesia \\ ${ }^{4}$ Faculty of Economics, Universitas Negeri Malang, Indonesia
}

\begin{tabular}{l}
\hline Article Info \\
\hline Article history: \\
Received: 4 June 2018; \\
Accepted: 28 September 2018; \\
Published: 10 October 2018.
\end{tabular}

Keywords:

Housing Affordability; Rural Area; House Ownership

\begin{abstract}
Barriers to entry of housing affordability are not only existed in urban but also in rural areas. This condition makes rural households difficult to obtain their own house. However, it is still common for them to ask help from parents, in term of financial support or buy the house for them. The purpose of this paper aimed at understanding the phenomenon of society in the rural area to meet their need for house ownership. This research used the descriptive method, employed 15 participants in the Village of Olak-Alen, District of Selorejo, Regency of Blitar, Indonesia. The results of this research showed that newly formed households find their most significant obstacle to own house is inadequate income. Their low income is majorly caused by lack of financial literacy and insufficient work experience.
\end{abstract}

\begin{abstract}
Abstrak
Hambatan masuknya keterjangkauan perumahan tidak hanya ada di perkotaan tetapi juga di daerah pedesaan. Kondisi ini membuat rumah tangga pedesaan sulit mendapatkan rumah sendiri. Namun, masih biasa bagi mereka untuk meminta bantuan dari orang tua, dalam hal dukungan keuangan atau membeli rumah untuk mereka. Makalah ini bertujuan memahami fenomena masyarakat di daerah pedesaan untuk memenuhi kebutuhan mereka akan kepemilikan rumah. Penelitian ini menggunakan metode deskriptif, dengan 15 responden di Desa Olak-Alen, Kecamatan Selorejo, Kabupaten Blitar, Indonesia. Hasil penelitian ini menunjukkan bahwa rumah tangga yang baru dibentuk, menemukan hambatan paling signifikan untuk memiliki rumah yaitu pendapatan yang tidak memadai. Penghasilan rendah mereka terutama, disebabkan oleh kurangnya literasi keuangan dan pengalaman kerja yang tidak mencukupi.
\end{abstract}

How to Cite:

Soseco, T., Wulandari, D., Hadi Utomo, S., \& Narmaditya, B. (2018). House Ownership Circumstances in Rural Area in Indonesia. Jurnal Pendidikan Ekonomi Dan Bisnis (JPEB), 6(2), 93-102. https://doi.org/https://doi.org/10.21009/JPEB.006.2.2

* Corresponding Author.

Thomas Soseco : thomassoseco@gmail.com

Dwi Wulandari : dwi.wulandari.fe@um.ac.id

2302-2663 (online)

Sugeng Hadi U : sugeng.hadi.fe@um.ac.id

Bagus Shandy N : bagus.shandy.fe@um.ac.id 


\section{INTRODUCTION}

Housing affordability problems have risen among young people. This situation is more criticial after they reach their marriage. As marriage resulting more space avaliable for families, it will create additional demand for housing. This condition exists in urban as well as rural areas.

In urban areas, people faces skyrocketing house price. As a consequences, they have to built relatively small house and usually this condition is worsened by poor income inequality. However rich people enjoy decent house while poor people only have options to live in less decent houses in slump areas. People in rural areas will experience relatively lower house price comparing to in cities. Since low demand of housing or other economic activity would create low increment in land price. Abundant land, together with low land price allow them to build relatively a large house. It will sufficient to accomodate all family members and in addition to extend family members. If not, they can get a piece of land from their parent. This tradition commonly found in medium and top social class. In contrary, lowest class of society will confront low income level because their inability to find high-income jobs.

Housing affordability can be defined as the ability of households and individuals to enter into home ownership (Kennett \& Chan, 2010). Households are seemed success to fulfill their basic needs if they able to afford houses. This concept also assumes that households should allow 30 per cent of their monthly income to housing expenditure. This number is acceptable since they have to spare their income to other daily needs. But this condition can be worsened in low-income households (Kennett \& Chan, 2010). Usually, they spend more than 30 per cent of their monthly income for housing expenditure. Furthermore, there will be fewer funds available to other daily needs, such as food, education, and health care (Soseco et al., 2017).

There are many factors that influence housing affordability namely Housing price,
Income Inequality, High saving rates, and Rural-Urban migration. High house price may prevent households' ability to obtain new houses (Saunders, 2016). In addition, Income inequality signficantly affect to house ownership (Quigley \& Raphael, 2004; Matlack and Vigdor, 2008, Zhang et al., 2016).

High-income inequality makes wealth accumulated in few people only. Majority of people, who have relatively low income, will feel hard to afford houses. Moreover, Higher saving rates that resulting from an unbalanced sex ratio (Wei et al., 2012). Unbalanced sex ratio leads to older marriage age. This will leads to higher savings. This condition is responded by house sellers to increase their selling price. Rural-urban migration (Garriaga et al., 2014). With more migrants fulfill cities, there will be tighter competition to obtain houses in urban areas.

Housing stress-the term used to describe the instability that people experience in the housing market-has differential impacts according to demographic and household characteristics (Costello, 2009). Housing stress includes the differing micro-scale impact that housing costs have on individual households. People aged 65 years or older are less likely to be subjected to housing stress as they traditionally have higher rates of homeownership. Costello (2009) stated that affordable housing should be considered more than simply a welfare solution and that it impacts a larger and wider cross-section of the community. Yates et al. (2007) and Costello (2009) argued that there are a number of gaps in housing affordability research, one of which is the unknown burden felt by moderate income earners who have to ultimately bear the burden of housing infrastructure outlays and/or transport costs. It is the condition when people have to live in new housing areas further from their offices.

In geographic perspectives, housing stress is more likely to be found in metropolitan areas. But, recent studies found 
that some attention should be directed to movement from metropolitan to nonmetropolitan areas. This is because unaffordable housing is presented as a key driver of a significant social reconfiguration of many areas (Hoggart \& Henderson, 2005), as adventitious purchasers enter rural markets and cause a distortion of prices (Shucksmith, 1990), reinforcing patterns of social exclusion and gentrification (Phillips, 1993). Burrows et al. (1998) mentioned that young people in rural areas face stiff competition for the limited supply of accommodation. This comes from more affluent rural households but also from the in -migration of groups such as commuters, households on retirement and those seeking second homes or making an investment in holiday lets.

Furthermore, Burrows et al. (1998) found that the failure to meet those housing needs has a series of consequences: First, young people will face continued pressures to leave rural areas; more reluctant leavers will actually leave. Second, young people currently committed to staying will find it more difficult to do so. Third, where they can stay, it may be at the cost of delaying the full transition to adult independence. Fourth, young people who do stay may have to commit substantial amounts of income to obtain independent housing. For those whose incomes are relatively low, this is likely to increase their risk of poverty.

Finally, all of these issues are likely to ensure that young people experiencing homelessness in rural areas have little opportunity to solve their problems by receiving help within the rural community and thus increasingly such homelessness may be exported to towns and cities.

The similar situation is explored by Costello (2009). The influx of people into rural areas has also led, for example, to some suggestions of the possibility of rural repopulation occurring. This counterurbanization is majorly caused by commuters (generally middle-class people moving to more attractive sectors within the rural fringe of the metropolis), retirees (drawn by lifestyle considerations and financial advantage to settle in non-metropolitan areas, e.g. the price differential between urban and rural housing), and welfare recipients. Similar to Gallent \& Robinson (2011) who found that some factors that reduce the affordability of housing in rural areas are divided into two groups: demand and supply. In the demand category, housing has been underpinned by a changing age structure, increased longevity, inward migration, and the formation of smaller households. While in supply category, the preservation of rural character, together with landscape protection are the main foci of land use planning in rural areas.

In general, rural population has resulted lower per capita income comparing to urban (BPS, 2016). Moreover BPS (2016) found that in urban areas, workers received by approximately 1.386 .000 rupiah per month, for white-collar (professional, technical, and skilled workers; executive and managerial workers; administrative and clerical workers), gray-collar (sales workers; Services workers), and blue-collar (agricultural workers, farmers, livestock farmers, forestry workers, fisherman and hunter; production workers, transport operators, and laborers). While in rural areas, they received about 1.232.300 rupiah per month. This low level earning among rural population creates fewer funds available to people to enhance their living standard. As housing costs occupy significant proportion of their income, there will be less income available education, food, transportation (Soseco, 2016).

As a result, there will be a vicious circle of poverty. The initial condition, low income, will affect to low capacity to enhance high income. This situation potentially makes young people in rural areas difficult not afford a house. Numerous studies explained housing affordability for urban areas (Chaplin \& Freeman, 2009; Hashim, 2010; Wetzstein \& Le Heron, 2010; Suhaida et al., 2011; Ball, 2011; Shakur et al., 2017).

However, there is few research related house affordability in rural areas. 
Furthermore, it is important to give more attention to Indonesia, which more than 60 per cent of its population live in rural areas. A failure to provide suitable situation for people to afford house will significantly enhance people living condition. Thus, it is important to investigates factors that prevent young rural households from owning houses.

\section{METHOD}

This is a qualitative descriptive research. We asked 15 participants to contribute to our survey. All of them are women, aged 25-40 years and involved in early marriages. We then developed question lists developed by Susilawati \& Wong (2014). The research is conducted in Desa (Village) Olak-Alen, Kecamatan (District) Selorejo, Kabupaten (Regency) Blitar, Province of Jawa Timur, Indonesia. Village of Olak-Alen is one of ten villages in District of Selorejo (Badan Pusat Statistik Kabupaten Blitar, 2015). Its location is near from main road connecting two big cities (Malang and Blitar). Also, it located near from two major tourism objects (Lahor and Karangkates Dam). Our focus area is based on rural typology from Lowe \&
Ward (2009). Their simplified typology can be seen in table 1.

Based on table 1, Village of Olak-Alen is considered as 'deep rural areas'. Lowe \& Ward (2009) explained deep rural areas would resonate most closely with popular perceptions of the 'traditional' countryside. Conventional livestock farming is more prominent, together with rural tourism. Population density is way below the rural mean, creating a pervading sense of tranquillity. In other respects, though, Deep Rural areas seem to lack sufficient symbolic resources to attract in those socio-economic classes that are underpinning the vibrancy of the 'commuter' categories.

Population change is only at the rural average, there being neither significant inmigration nor much commuting. Physical remoteness and poor infrastructure (for example, of information and communication technology networks or motorways) explain some of the situation.

Table 1. Rural Area Types Generated by the Cluster Analysis

\begin{tabular}{|c|c|c|}
\hline No. & Type & Description \\
\hline 1. & $\begin{array}{l}\text { Dynamic } \\
\text { commuter areas }\end{array}$ & Socially and economically dynamic and affluent \\
\hline 2. & $\begin{array}{l}\text { Settled } \\
\text { commuter areas }\end{array}$ & $\begin{array}{l}\text { Share characteristics with the first type, but tend to be less vibrant, } \\
\text { more settled and more provincial, often associated with other city } \\
\text { regions. commuter hinterlands of regional hubs, }\end{array}$ \\
\hline 3. & $\begin{array}{l}\text { Dynamic rural } \\
\text { areas }\end{array}$ & $\begin{array}{l}\text { Have high density of professional and knowledge workers, } \\
\text { sometimes being associated with universities or other research } \\
\text { centres. }\end{array}$ \\
\hline 4. & $\begin{array}{l}\text { Deep rural } \\
\text { areas }\end{array}$ & $\begin{array}{l}\text { Countryside that still dependent on farming but with increasingly } \\
\text { important tourism element and less reliance on commuting. } \\
\text { Sparsely populated farming communities. }\end{array}$ \\
\hline 5. & $\begin{array}{l}\text { Retirement } \\
\text { retreat areas }\end{array}$ & $\begin{array}{l}\text { Comprise popular retirement destinations and have ageing } \\
\text { populations. }\end{array}$ \\
\hline 6. & $\begin{array}{l}\text { Peripheral } \\
\text { amenity areas }\end{array}$ & $\begin{array}{l}\text { Located in economically marginal zones, particularly on the coast, } \\
\text { that may have suffered structural economic decline and are now } \\
\text { propped up by tourism or retirement-related services. }\end{array}$ \\
\hline 7. & $\begin{array}{l}\text { Transient rural } \\
\text { areas }\end{array}$ & $\begin{array}{l}\text { Situated close to struggling urban centres, associated with } \\
\text { commuting, but also associated with low incomes. Near to declining } \\
\text { market towns, former mining areas, etc. }\end{array}$ \\
\hline
\end{tabular}

Source: Lowe \& Ward (2009); Gallent \& Robinson (2011) 


\section{RESULTS AND DISCUSSION}

All of our respondents are female, with an average age of 33 years old. More than half of them have senior high school (year 1618) as their highest education attainment. Followed by junior high school (year 13-15) and elementary school (7-12). More than 80 per cent of them are housewives while the rest work full time.

In general, our respondents married at age 22 . While their spouses, on average, are 27 years old at their marriages. The earliest are at marriage is at 16 years old. They have, on average, 2 children. Our respondents have monthly income Rp. 2.133.333, with maximum value Rp. 4.000.000 and minimum value Rp. 1.000.000. Approximately by 61.54 per cent of our respondents stated that their income is not sufficient to fulfill their needs, while the rest was about 38.46 per cent stated the contrary situation. More detail, this situation is shown in figure 1.

It can be seen form figure 1 , where the majority of respondents are not able to fulfill their daily needs, gives implication that they cannot spend a certain amount of their income to savings and investment. There were only 33.33 per cent of our respondents stated that they can save a certain amount of money each month, which range between $\mathrm{Rp}$. 100.000 to Rp. 2.000.000.

Figure 2 provides information about the housing status. There were about 40 per cent of respondents mentioned that they cannot save a certain amount of money each month, while the rest $26.67 \%$ preferred not to answer. In relationship to housing status, 46.67 per cent of our respondents bought their current house after marriage. While 40 per cent said that status of their current house is parents' or relatives' house. Lastly, as much as 13.33 per cent indicated that their current house is a gift from their parents or relatives. Discussing where new couples should live after their marriages, majority (92.31 per cent) of our respondents stated that they have to live in their own house. Only 7.69 per cent said that new couples should live in parents/relatives' house. Our respondents agreed that new couples are allowed to live in their parents' house in their early years of marriages, on average for 28.1 months. The maximum value is 60 month and the minimum one is 1 month.

\section{Housing Affordability}

Most of our respondents as much as 85.71 per cent stated the main factor of housing unaffordability is insufficient income needed to buy house. While the rest, was about 14.29 per cent respondent stated that the main problem is the high house price.

More specifically, Figure 3 explains how households give opinion that people have to provide cash to buy new house. They have to provides 50-100 million rupiah (40\%) and more than 150 million rupiah (40\%) and 100150 million rupiah (20\%). In their opinion, that amount of money is not able to be collected by people in their community. There are approximately by 53.85 per cent who said that it will not able for them and about 46.15 per cent that mentioned it is able to them. The majority of respondents $(86,67 \%)$ stated that the best way to obtain a certain amount of money to afford house is through work harder. Whilst other, was about 13.33 per cent said that the best way is through work overseas.

Related to that situation, our respondents stated that the main cause why households cannot obtain high income are insufficient work experience/expertise and lack of financial planning. Each of those reasons is supported by 40 per cent of respondents. Next, 6.67 per cent stated that low education level affect to the low income. While the rest 6.67 per cent respondents said that low paid job causes low income received. All of those reasons make households are not able to gain higher income and finally prevent high savings accumulation.

Figure 4 shows the factors that influencing low income among people are insufficient work experience, lack of financial literacy, low education, low paid jobs, and others. Insufficient work experience is strongly related with low education level. Our respondents implied that senior high school (year 16-18) are their highest 
Soseco, T., Wulandari, D., Hadi Utomo, S., \& Narmaditya, B./ Jurnal Pendidikan Ekonomi \& Bisnis, 6 (2) 2018, 93-102

education attainment. This condition makes sector. Thus, they will join informal sector, them difficult find employment in formal

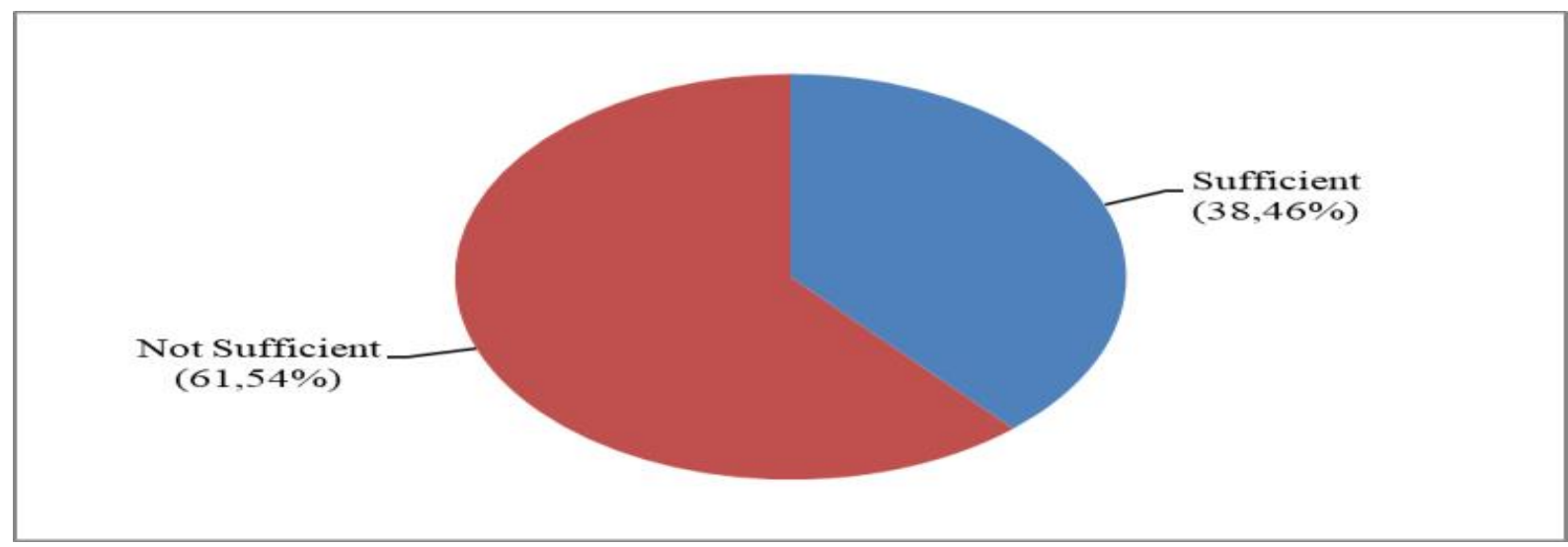

Figure 1. Income Sufficient Source: Data processed

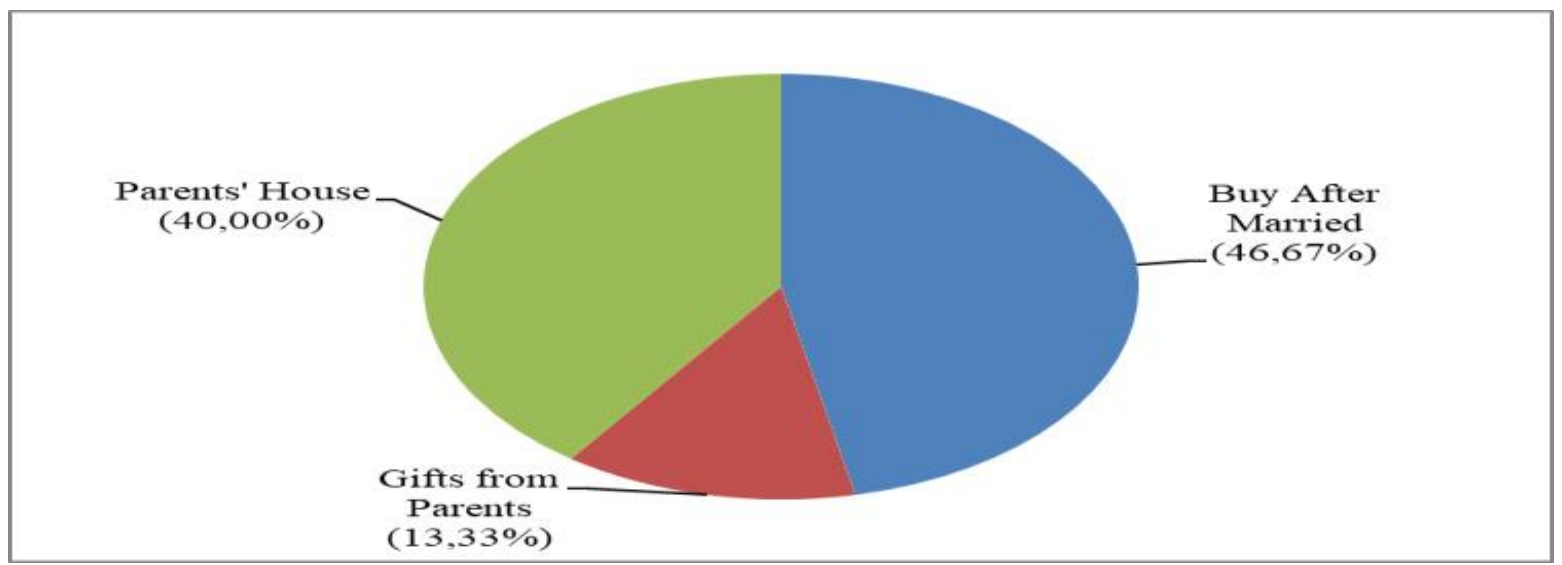

Figure 2. Housing Status Source: Data processed

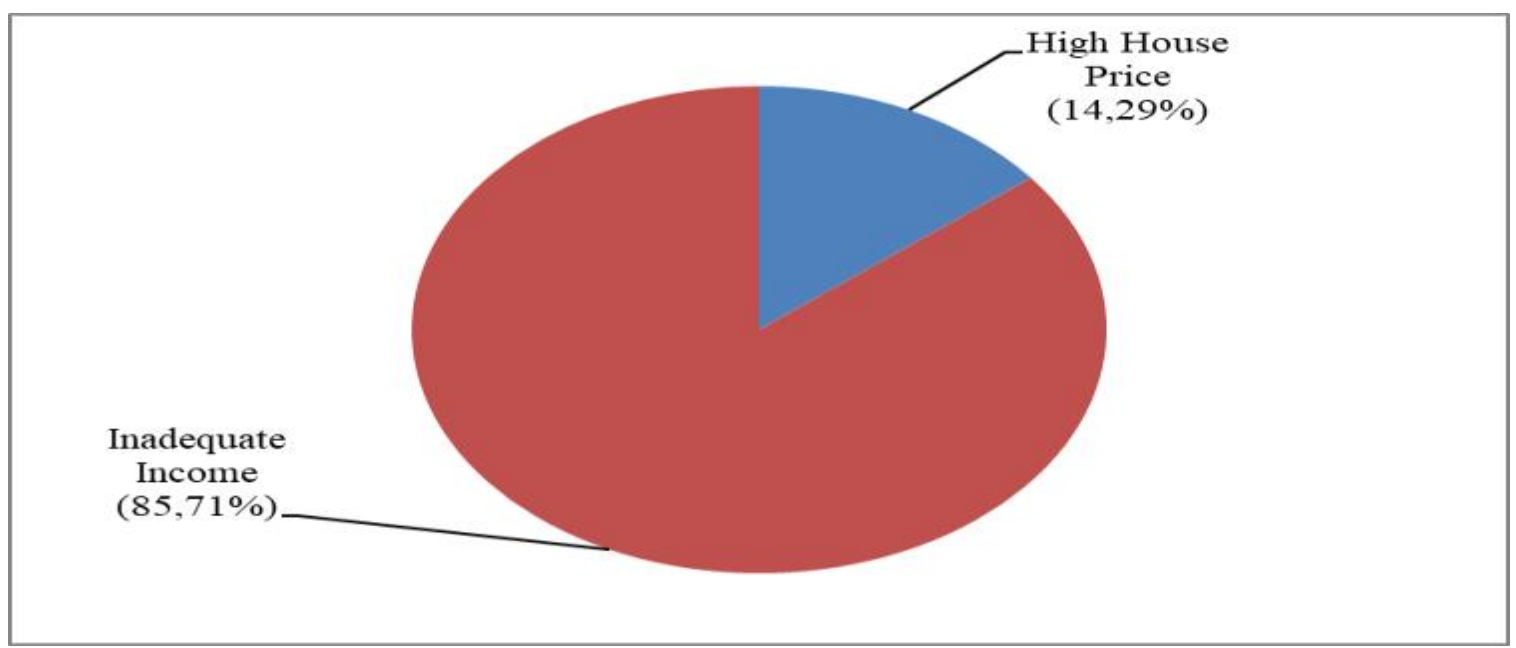

Figure 3. Factors that Influence Housing Affordability 
for example in agriculture workers, traders, sector give relatively low income for them. or construction workers. This employment

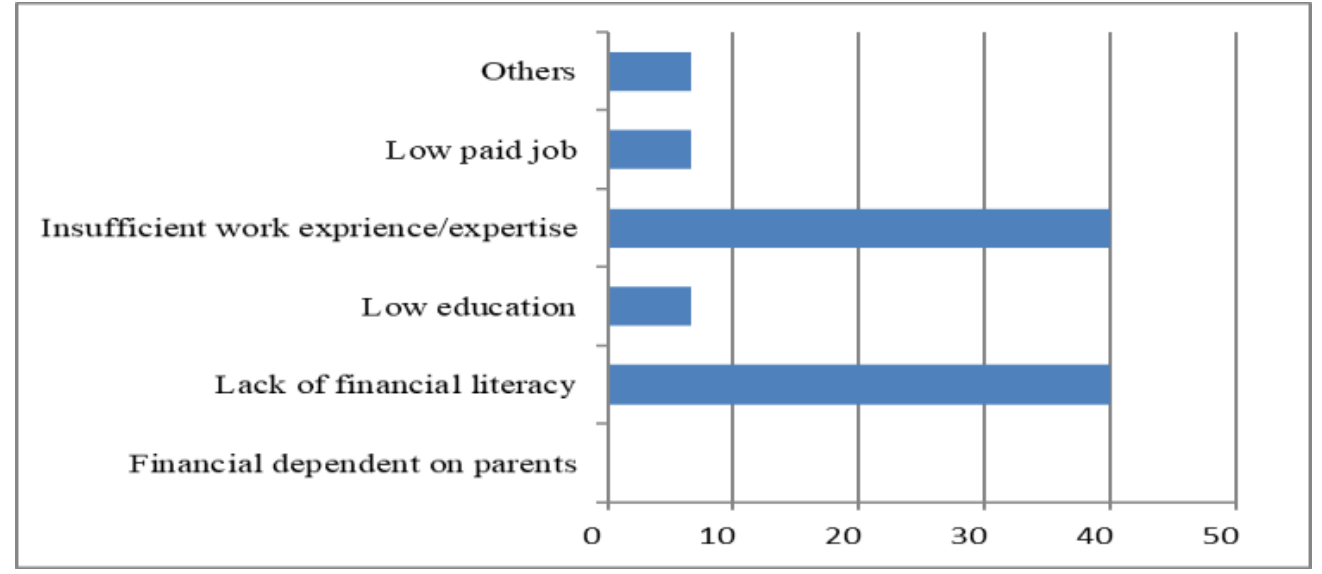

Figure 4. Factors that Causes Low Income

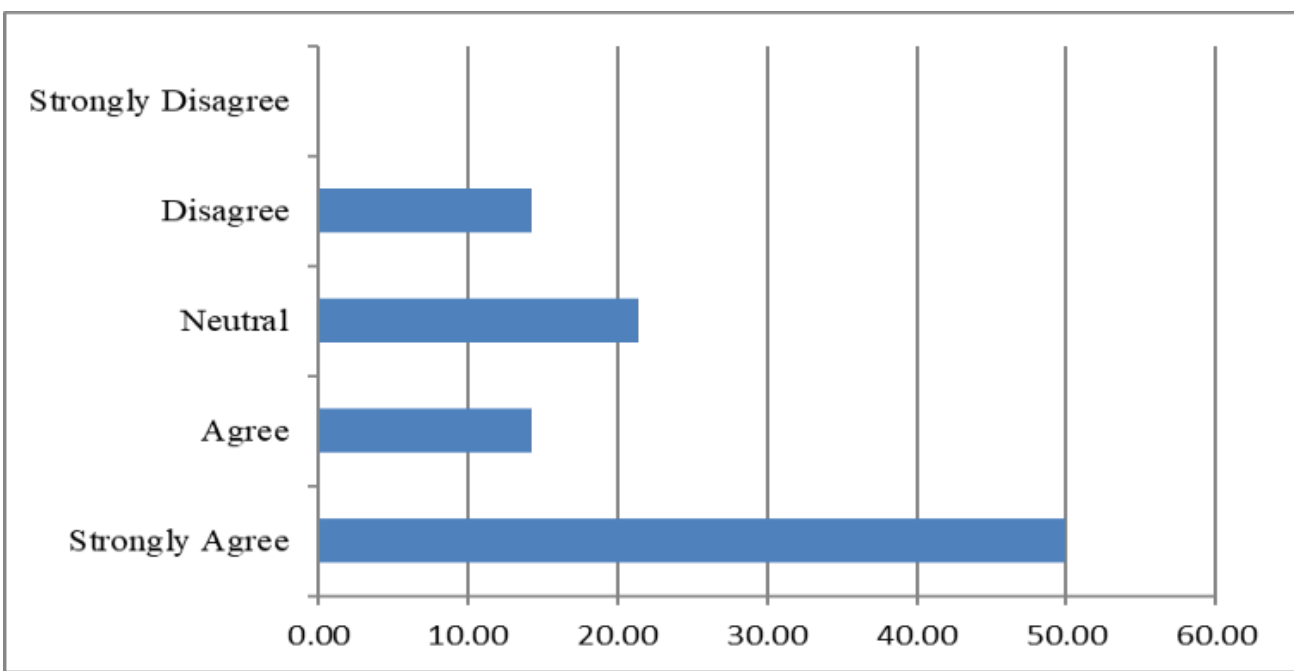

Figure 5. Housing Cost is the Major Barrier of Accessibility to Affordable Housing

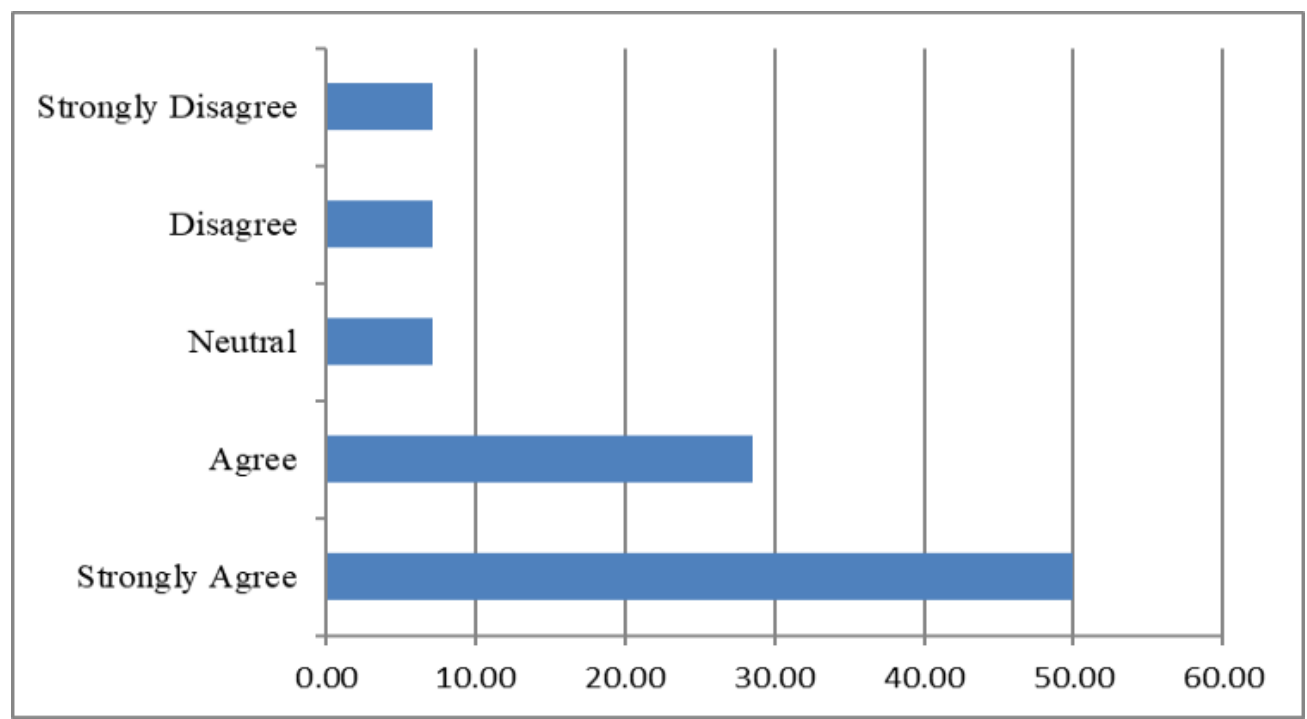

Figure 6. Low Income is the Major Barrier of Accessibility to Affordable Housing 
Simultaneously, their low income also leads to their inabilty to access infomation in order to enhance their financial literacy.

Figure 5 Illustrates that Housing Cost is the Major Barrier of Accessibility to Affordable Housing half respondents strongly agree that housing cost and low income are the major barrier of accessibility to affordable housing. While in Figure 6 provides information how Low Income is the Major Barrier of Accessibility to Affordable Housing. With more people give score 'agree' and 'strongly agree' to low income than housing cost $(78 \%$ versus $63 \%)$, gives implication that low income has higher effect on housing affordabilty. Later, we investigate what solutions needed to overcome housing affordability problem in Village of Olak-Alen.
We found that respondents prefer to work harder to solve that issue, than to ask parents' help ( See Figure 7 and Figure 8).

From figure 7, parents' help seemed to be avoided by young households in Village of Olak-Alen in pursuing their own houses. Eventhough most of them feel that their income is not sufficient to fulfill their daily needs (Figure 1), but approximately 56 per cent of respondents disagree and 21 per cent strongly disagree to find parents' help to overcome affordability problem.

On the other hands, 72 per cent of respondents strongly agree (with additional 21 per cent agree) to work harder is the best way to solve affordability problem.

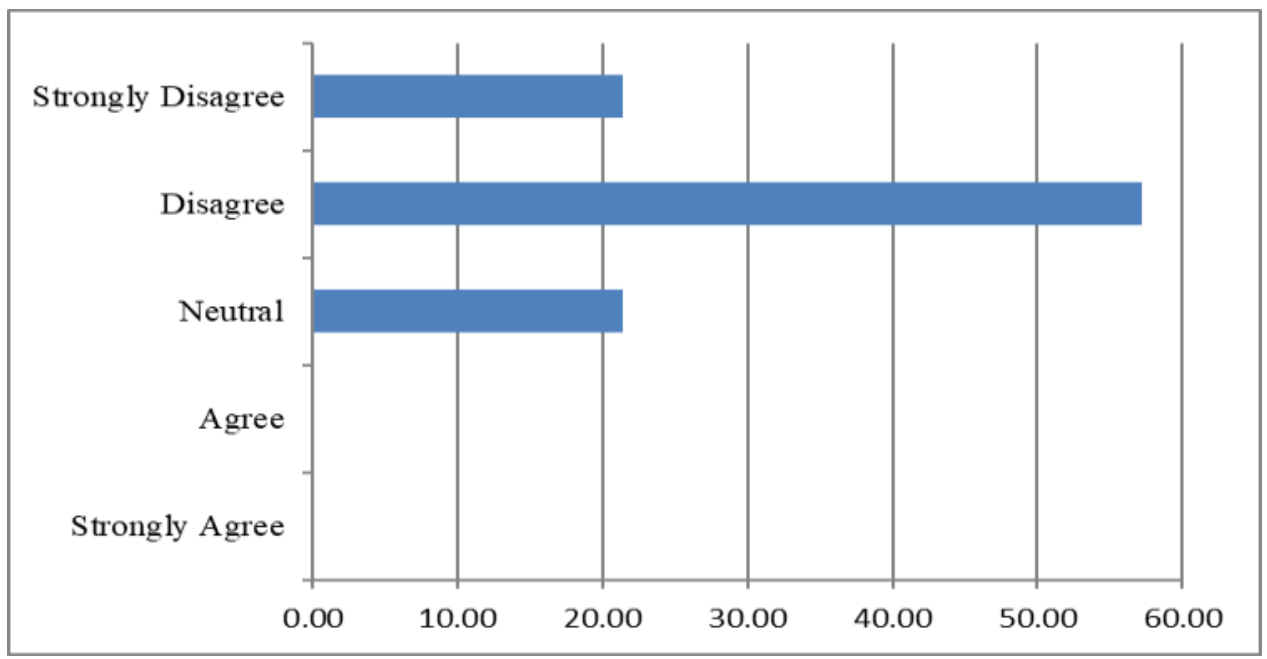

Figure 7. Find parents' help is the best way to solve affordable housing problems

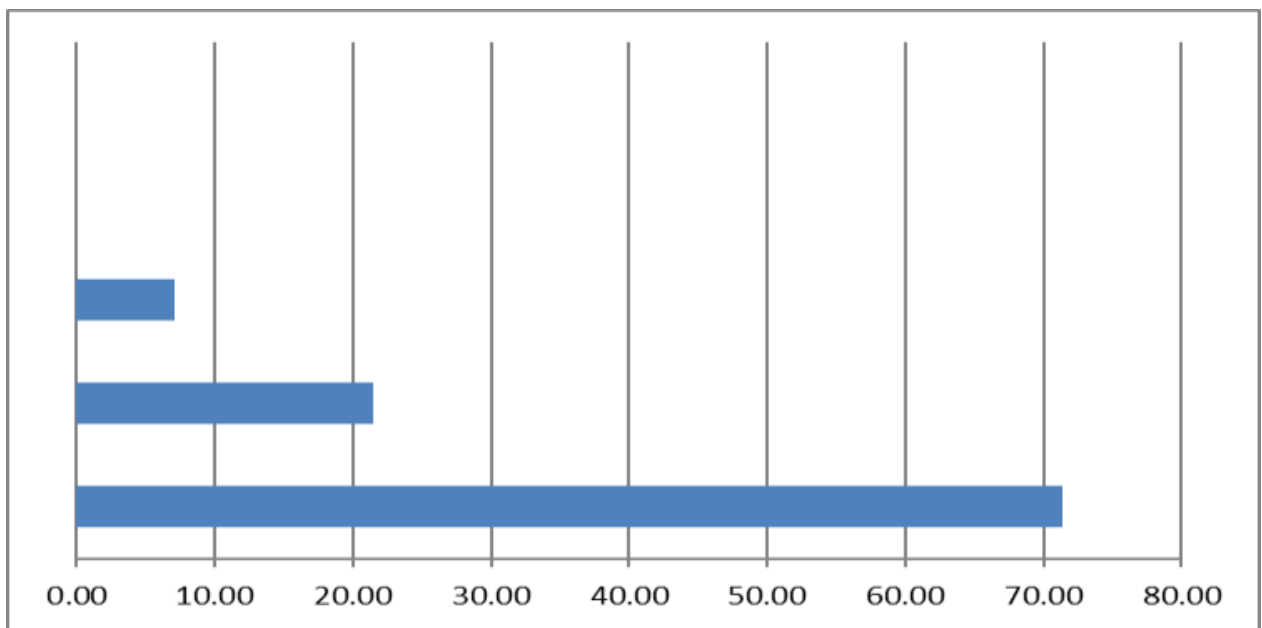

Figure 8. Find better job is the best way to solve affordable housing problems 


\section{CONCLUSION}

Housing ownership problems is rosen from people's ability to find a house. This will drives their inability to provide adequate house for their family. As a result, people will select to live in dwellings that create a relatively low expenditure for them. Thus. They will live in less decent houses which later creates slump areas. This condition will create families' inability to find better job which can give high income. In the Village of Olak-Alen, which considered as 'deep rural areas', most of its population perceived that their income is not sufficient to fulfill their daily needs. This condition also exist in other rural areas. This is majorly caused by insufficient work experience and lack of financial literacy. Insufficient work exprience causes low productivity that causes them cannot find better jobs. Others, lack of financial literacy drives to people inability to select best choices for them.

Finally, they cannot enhance their living standard. Related to housing affordability, the respondents believe that high house price is not a significant barrier for them to afford new houses. This condition is mainly caused by a relatively low house price. In people's perception, insufficient income is the major issue for them to afford houses. Again, this condition is caused by insufficient work experience and lack of financial literacy. The best solution to overcome this problem is not ask for parents' help but work harder.

\section{REFERENCES}

Ball, M. (2011). Planning delay and the responsiveness of English housing supply. Urban Studies, 48(2), 349-362.

BPS. (2016). Statistik Pendapatan Agustus 2016. Retrieved from https:// www.bps.go.id

Burrows , R., Ford, J., Quilgars, D., \& Pleace, N. (1998). A Place in the Country? The Housing Circumstances of Young People in Rural England. Journal of Youth Studies, 1(2), 177-194.

Chaplin, R., \& Freeman, A. (1999). Towards an Accurate Description of Affordability. Urban Studies, 36(11), 1949-57.

Costello, L. (2009). Urban-rural Migration: Housing Availability and
Affordability. Australian Geographer, 40(2), 219-233.

Gallent, N., \& Robinson, S. (2011) Local Perspectives on Rural Housing Affordability and Implications. Journal of Rural Studies, 27(2011), 297-307.

Garigaga, C., Manuelli, R., \& Peralta-Alva, A. (2014). A Model of Price Swings in the Housing Market. Working Paper.

Hashim, Z. A. (2010). House Price and Affordability in Housing in Malaysia. Journal of Southeast Asia Social Sciences and Humanities, 78(1), 37-46.

Hoggart, K. \& Henderson, S. (2005). Excluding Exceptions: Housing Nonaffordability and the Oppression of Environmental Sustainability? Journal of Rural Studies, 21, 181-196.

Kenneth, P., \& Chan, K.W. (2010). Women and Housing: An International Analysis. London: Routledge.

Lowe, P. \& Ward, N. (2009). England's Rural Futures: A Socio-Geographical Approach to Scenarios Analysis, Regional Studies, 43(10), 1319-1332.

Phillips, D. (1993). Report on the Housing Preferences of Black and White Applicants for Housing in the London Borough of Lewisham. Unpublished Report Submitted to the London of Lewisham.

Phillips, M., (1993). Rural Gentrification and the Process of Class Colonisation. Journal of Rural Studies, 9(2), 123140.

Quigley, J. M., \& Raphael, S. (2004). Is Housing Unaffordable? Why Isn't it More Affordable?. Journal of Economic Perspectives, 18(1), 191-214.

Saunders, P. (2016). Housing Costs, Poverty and Inequality in Australia. Housing Studies, 32(6), 742-757.

Shakur, E.S.A., Mohamed, A. F., \& Hadi, A.S.A. (2017). House Affordability Factors For Urban Liveability - A Preliminary Study. International Journal of Property Science, 17(1), 1-14.

Shucksmith, M., (1990). A Theoretical Perspective on Rural Housing: Housing Classes in Rural Britain. 
Sociologia Ruralis, 30(2), 210-229.

Soseco, T. (2016). The Relationship between Rural Accessibility and Development. Jurnal Ekonomi dan Studi Pembangunan, 8(2), 31-40.

Soseco, T., Sumanto, A., Soesilo, Y.H., Mardono, Wafa, A.A., Istiqomah, N., Yunikawati, N.A., \& Puspasari, E.Y. (2017). Income Inequality and Access of Housing. International Journal of Economic Research, 14(5).

Susilawati, C., \& Wong, L.R. (2014). Barriers to Entering Affordable Home Ownership for Young People: A Preliminary Study from University Students' Perspectives. Paper Presented in 20th Annual Pacific-Rim Real Estate Society Conference, Christchurch, New Zealand, 19-22 January 2014.

Vigdor, J. (2008). The economic aftermath of Hurricane Katrina. Journal of Economic Perspectives, 22(4), 135-54.

Wei, S., Xiaobo, Z., \& Yin, L .(2012). Status Competition and Housing Prices:
Some Evidence from China. Working Paper, Columbia University.

Wetzstein, S., \& Le Heron, R. (2010). Regional economic policy 'in-the-making': Imaginaries, political projects and institutions for Auckland's economic transformation. Environment and Planning A, 42(8), 1902-1924.

Yates, J, Milligan, V, Berry, M, Burke, T, Gabriel, M, Phibbs, P, Pinnegar, S., \& Randolph. (2007). Housing Affordability: A 21st Century Problem, AHURI Final Report No. 105, September 2007.Zhang, X., Liu, X., Hang, J., Yao, D., \& Shi, G. (2016). Do urban rail transit facilities affect housing prices? Evidence from China. Sustainability, 8(4), 380. 